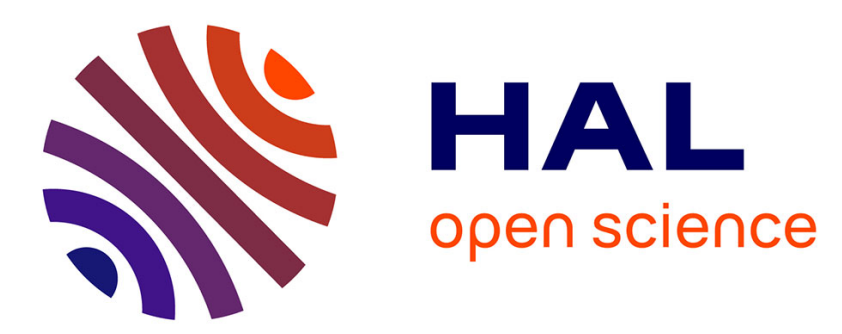

\title{
Using phylogeography to define conservation priorities: The case of narrow endemic plants in the Mediterranean Basin hotspot
}

Frederic Medail, Alex Baumel

\section{> To cite this version:}

Frederic Medail, Alex Baumel. Using phylogeography to define conservation priorities: The case of narrow endemic plants in the Mediterranean Basin hotspot. Biological Conservation, 2018, 224, pp.258 - 266. 10.1016/j.biocon.2018.05.028 . hal-01851876

\section{HAL Id: hal-01851876 \\ https://hal.science/hal-01851876}

Submitted on 31 Jul 2018

HAL is a multi-disciplinary open access archive for the deposit and dissemination of scientific research documents, whether they are published or not. The documents may come from teaching and research institutions in France or abroad, or from public or private research centers.
L'archive ouverte pluridisciplinaire HAL, est destinée au dépôt et à la diffusion de documents scientifiques de niveau recherche, publiés ou non, émanant des établissements d'enseignement et de recherche français ou étrangers, des laboratoires publics ou privés. 
Special issue of Biological Conservation: "Which rarity to conserve"

\title{
Using phylogeography to define conservation priorities: the case of narrow endemic plants in the Mediterranean Basin hotspot
}

\author{
Frédéric Médail*, Alex Baumel
}

Institut méditerranéen de biodiversité et d'écologie marine et continentale (IMBE), Aix Marseille Université, CNRS, IRD, Avignon Université. Campus Aix, Technopôle de l'Environnement Arbois-Méditerranée, 13545 Aix-en-Provence cedex 4, France

* Corresponding author

E-mail addresses: frederic.medail@imbe.fr, alex.baumel@imbe.fr

\section{A B S T R A C T}

The preservation of rare and vulnerable narrow endemics is a key issue in biological conservation since they represents distinct evolutionary units emerging from various temporal processes. Phylogeography has proved to be a relevant tool for the distinction of evolutionary structures resulting from contrasted biogeographical events. However, the historical and evolutionary perspective provided by phylogeography is still curiously underused in plant conservation genetics. Here we perform a comprehensive review of almost all case studies related to the structure of genetic diversity of Mediterranean narrow endemic plants (MNEs) of the Mediterranean Basin hotspot. The use of genetic diversity structure for phylogeographical inference and for the definition of conservation units was examined for ninety-two studies corresponding to eightythree taxa. Most of these taxa are perennial herbs with a narrow ecological niche. Geographical coverage is heavily biased since $91.5 \%$ of the analyzed MNEs are located in the north-western part of the Mediterranean region. Half of the studied species have moderate to high genetic diversity, and genetic differentiation is geographically structured in $56 \%$ of the case studies indicating that MNEs are not "evolutionary deadends" but are sheltering a strong evolutionary legacy calling for conservation planning at populations' level. However, a minority of studies used these genetic structures to define conservation units. The main insight of this review is that phylogeography is generally overlooked in conservation genetics and that the design of conservation units has not been a priority issue, rather a way to enhance the scope of genetic diversity analyses. Nevertheless, the strong phylogeographic structure revealed in several studies of MNEs underlines the relevance of phylogeography and we argue that comparative phylogeography of several co-occurring taxa could greatly improve the proactive conservation planning of threatened endemic plants within biodiversity hotspots.

Keywords:

Biogeography, Conservation genetics, Conservation units, Evolutionary legacy, Mediterranean hotspot, Narrow endemics, Phylogeography, Rare species 


\section{Introduction}

Facing rapid environmental and biodiversity changes worldwide, it is necessary to go beyond the taxonomic diversity and to consider the putative large gains offered in conservation biology by the other facets of biodiversity, namely evolutionary diversity and functional diversity (Pollock et al. 2017). If there is an increasing interest to include these metrics in community ecology, biogeography and conservation (Devictor et al., 2010; Mouquet et al. 2012, Jarzyna \& Jetz 2016), there are still some gaps in this fruitful approach.

First, the dimension of evolutionary diversity or evolutionary rarity is quasi exclusively considered by the phylogenetic attributes of species, because of the facilitated use of phylogenetic trees in conservation prioritization (Tucker et al. 2012, Pollock et al. 2015). This is the domain of ecophylogenetics that merges ecology, biogeography and macroevolution (Mouquet et al. 2012). But this macroevolutive perspective masks the need to consider also the evolutionary diversity at a finer regional or local spatial scales, and at the level of species or populations. To fill this gap between multispecies phylogenetic studies and intraspecific phylogeography will allow to better take into account the evolutionary continuum into conservation prioritization (Lexer et al. 2013, Carvalho et al. 2017) (Figure 1).

Second, most of the studies of evolutionary conservation have focused on large datasets of species irrespective of the consideration of their rarity degree (but see Cadotte \& Davies 2010). However, the contribution of rare species to predict the impacts of biodiversity loss is crucial, since rare species often being the first to go extinct (Gaston 1994, 2012). Furthermore, rare species that are often characterized by low functional redundancy, are likely to support the most vulnerable functions, even in highly diverse ecosystems (Mouillot et al. 2013).

Third, very few studies examining biodiversity facets concerns plants (Forest et al. 2007, Thuiller et al. 2014); however, this group is not governed by the same spatiotemporal processes as most of the vertebrates for example, and the key role of local persistence - notably in severe environmental conditions - must be also considered (García \& Zamora 2003).

Within the framework of the conservation genetics, the consideration of phylogeography to set Conservation Units (CUs) aims to conserve the evolutionary legacy within species mainly related to isolation process and historical biogeographical events (Ryder 1986, Moritz 1994, Moritz \& Potter 2013). But this approach has been addressed almost exclusively for vertebrate species and very few studies concern plants (e.g. Swarts et al. 2014, Pouget et al. 2017). This distortion between conservation genetics approaches and the numerous insights of phylogeographic studies for plants is quite surprising. Indeed, approaches of multiple facets of rarity for conservation need to consider both phylogenetic diversity but also evolutionary structures of the populations of rare and threatened taxa. This would undoubtedly lead to better conservation prioritization efforts of rare and endangered taxa according to their biogeographical structure, notably within biodiversity hotspots.

Among plants that are naturally restricted in terms of global distribution range, narrow endemic species (see Materials and methods for definition) are the target of much conservation attention because of their often reduced, isolated and threatened populations (e.g. López-Pujol et al. 2013, Jiménez-Mejías et al. 2015). But again, few 
studies have defined and taken into account CUs for an effective conservation biogeography (Ladle \& Whittaker 2011) of these range-restricted plants and the centres of endemism they mainly define, which are however areas of high conservation concern. Distribution of abnormally high concentrations of narrow endemics can be linked to the local accumulation of palaeoendemic or neoendemic plant species, with the predominant role of long-term stable environments or high topographical heterogeneity respectively (Molina-Venegas et al. 2017). But often, centres of endemism combine these two environmental drivers and they are indicative of refuge areas that have experienced a long-term stability of climate and habitats on a reduced spatial scale (e.g. Jetz et al. 2004, Ohlemüller et al. 2008, Médail \& Diadema 2009, Sandell et al. 2011, Harrison \& Noss 2017).

In the present review, we examine the contributions of phylogeography to the conservation prioritization of narrow endemic plants within the Mediterranean Biogeographic Region (MBR) (see Materials and methods), one of the 36 biodiversity hotspots of the world (Médail \& Myers 2004). This important plant diversity (ca. 30,000 species and subspecies $=$ taxa) is mainly concentrated within the 10 regional biodiversity hotspots (Médail \& Quézel 1997), in which we can distinguish smaller ones (Cañadas et al. 2014). These areas are characterized by an exceptional concentration of endemic species, notably range-restricted taxa. As quoted by Thompson (2005), narrow endemism represents 'the cornerstone of Mediterranean plant diversity': somewhere close to $60 \%$ of all native taxa occur only in the MBR and more than one-third (ca. $37 \%$ ) of the native flora corresponds to narrow endemic species (Greuter, 1991), i.e. an huge number estimated of ca. 11,000 narrow endemic taxa. But, this Mediterranean hotspot faces a biome crisis due to strong disparities between habitat loss and protection levels, particularly in the southern and eastern Mediterranean (Hoekstra et al. 2005). Global change threatens the current plant biodiversity, and species distribution modelling suggests a high degree of range contraction for narrow endemics in the MBR (Casazza et al. 2014). Because current genetic variation can play a major role in providing resilience and local adaptation to future change (e.g. Nielsen et al. 2016), it is important to examine if this genetic metric is properly considered into conservation planning of Mediterranean narrow endemic plants (MNEs). Previous studies have shown that despite their narrow geographical ranges MNEs can be characterized by several lineages and CUs concerned by different threats (e.g Pouget et al. 2017).

We perform a comprehensive review of the studies dealing with genetic diversity structure of narrow endemic plants in the Mediterranean Basin (i) to examine the relevance of phylogeography for the conservation of this priority biological contingent, (ii) to point out the crucial necessity to better include phylogeography into the framework of conservation of the multiple facets of rarity. 


\begin{tabular}{|c|c|c|}
\hline $\begin{array}{l}\text { Complementary } \\
\text { approaches }\end{array}$ & $\begin{array}{c}\text { Phylogeography } \\
\text { sensu lato }\end{array}$ & $\begin{array}{c}\text { Applications to } \\
\text { conservation } \\
\text { genetics }\end{array}$ \\
\hline \multicolumn{3}{|c|}{ Single taxon (single species or closely related species) } \\
\hline $\begin{array}{l}\text { Systematics } \\
\text { Biogeography }\end{array}$ & $\begin{array}{l}\text { Resolution of unpredictable patterns } \\
\text { of genetic structure } \\
\text { •Taxonomic uncertainities } \\
\text { •Evolutionary significant units } \\
\text { (ESUs) }\end{array}$ & $\begin{array}{l}\text { ESUs as } \\
\text { outcomes of past } \\
\text { and ongoing } \\
\text { diversification }\end{array}$ \\
\hline $\begin{array}{l}\text { Population } \\
\text { biology }\end{array}$ & $\begin{array}{l}\text { Better understanding of } \\
\text { diversification } \\
\text { •Spatial level: barriers, } \\
\text { isolation by distance or by } \\
\text { environment, admixture } \\
\text { •Population level: refugia, } \\
\text { expansion, demographic } \\
\text { bottleneck }\end{array}$ & $\begin{array}{l}\text { Incorporation of } \\
\text { evolutionary } \\
\text { processes in } \\
\text { conservation }\end{array}$ \\
\hline \multicolumn{3}{|c|}{ Multiple taxa (several species across several phyla) } \\
\hline $\begin{array}{l}\text { Historical } \\
\text { biogeography } \\
\text { Macroecology }\end{array}$ & Comparative phylogeography & $\begin{array}{l}\text { Conservation } \\
\text { biogeography }\end{array}$ \\
\hline
\end{tabular}

Figure 1: Conceptual position of phylogeography sensu lato and implications for conservation (from Diniz-Filho et al. 2008, Avise 2009). 


\section{Methods}

\subsection{Definition of narrow endemism}

Narrow endemism, also known as micro-endemism, local endemism, range-restricted endemism or short-range endemism, is a common form of rarity used to describe very small areas of distribution of taxa (eg., Kruckeberg \& Rabinowitz 1985; Gaston 1994; Caesar et al. 2017). Nevertheless, the geographical quantification of narrow endemism is difficult because it depends on the biogeographical history of the region under consideration, on its geographic structure (notably isolation's degree), on the environmental determinants, on the genetic structure and on the dispersal capacities of each taxon, but also on more subjective parameters such as the taxonomic bias and the scaling effects of the chosen area of study (Kruckeberg \& Rabinowitz 1985; Peterson \& Watson, 1998). All these factors explain why there are so many causes promoting endemism, and why there is no exclusive definition of narrow endemism. López-Pujol et al. (2013) defined 'extremely narrow endemics' as 'those plant taxa that usually occur in one or very few populations (five or fewer) that total very small species' census sizes (500 or fewer individuals, including reproductive and vegetative)'. This corresponds to the definition of Kruckeberg and Rabinowitz (1985) which considers 'truly narrow endemics' as extremely local rarities. Since this is the extreme situation of a restricted distribution range for a taxon and it concerns relatively few taxa, we preferred to consider a broader definition of narrow endemism. In this study, a narrow endemic plant is defined as a taxon whose totality (or nearly all, i.e. at least $90 \%$ of its occurences) of its populations are distributed within a narrow biogeographical entity, i.e. at the province level or below within the MBR.

\subsection{Definition of the Mediterranean Biogeographic Region (MBR)}

We considered in this review the narrow endemics present in the Mediterranean Biogeographic Region (MBR) defined on the basis of bioclimatic, biogeographical and phytoecological criteria, following the proposal of Médail and Quézel (1997). Its contours mainly follow, in the northern part, on the maps of vegetation of Europe and of the eastern Mediterranean (Quézel \& Barbero 1985); the 100-mm isohyet of annual rainfalls remains the standard for defining the southern boundary between the Mediterranean region, versus the Sahara to the south and the Irano-Turanian region to the south-east. The defined MBR thus covers an area of around 2,300,000 $\mathrm{km}^{2}$. This practical biogeographical limit has since been used by many international organizations (UNEP/Blue Plan, Conservation International, Critical Ecosystem Partnership Fund). In biogeographical and ecological terms, it is more realistic than a simple approach based solely on climatic factors and not plant assemblages (Klausmeyer \& Shaw 2009), that provides a too restrictive delimitation of the Mediterranean biome. Of course, biogeographical ecotones or transition zones must be considered more than strict boundaries between regions, since in many cases eco-biogeographical limits are gradual (Blasi et al. 1999). It is the reason why we have also considered the narrow endemics that can be called sub-Mediterranean and located at the interface between the MBR and (i) the Euro-Siberian region with the Alps (e.g. Moehringia lebrunii, Primula allionii), the Pyrenees (Glandora oleifolia) or the Balkans (Paramoltkia doerfleri), and (ii) the 
Irano-Turanian region in Anatolia (e.g. Barbarea integrifolia, Centaurea wiedemanniana, Verbascum alyssifolium).

\subsection{Selection of narrow endemics of the MBR with their relevant attributes}

The list of the narrow endemics of the MBR with their respective characteristics is included in the supplementary material (Table A1). For data compilation to identify studies reporting the use of genetic data for narrow endemic plants of the MBR, we have searched in various databases for the key-word combination 'narrow endemic plant', 'Mediterranean region', 'phylogeography', 'genetic structure', 'genetic diversity', 'genetic variation' in the title. We have also considered further studies cited in these references. We have only kept the ones dealing with the genetic/phylogeographic structures of populations strictly located within the MBR and we have excluded pure phylogenetic studies and those including obscure genetic structure for some complex species group or genera. Our final data set includes 84 studies (see References A1) encompassing 83 narrow endemic plants (see Table A1). The taxonomy refers, without exception, to that adopted by The Plant List (www.theplantlist.org).

For each narrow endemic, we have assigned the biogeographical area in which it is distributed. Biogeographical regionalization is the prerequisite for a better understanding of species distribution (Kreft \& Jetz, 2010), and thus for a robust conservation biogeography framework. But as there is no modern and comprehensive biogeographical subdivision of the Mediterranean region at the province (or domain) and sector levels, we have used a combination of various works to characterize the distribution of each narrow endemic: (i) the maps of Rivas-Martínez et al. (2004) and Moreno Saiz et al. (2013) for the western and central Mediterranean; (ii) the maps of Quézel and Barbero (1985) and of Parolly (2004) for the eastern Mediterranean; (iii) the maps of Deil and Galan de Mera (1996) and of Meddour (2010) for North Africa.

Then, for each narrow endemic, we have considered the following items: (i) administrative geographical location; (ii) presence on mainland $v s$. island; (iii) presence or not within the 52 phylogeographic refugia of plants identified by Médail and Diadema (2009) in the MBR; (iv) presence or not within one of the 10 regional biodiversity hotspots of plants defined by Médail and Quézel (1997, completed); (v): ecology with edaphic preference and main habitats occupied, and niche breadth approximated by altitudinal range and ecological specialization, according to indications of national or regional floras or Red data books (see below); (vi) ecological distinctiveness (measures of floristic composition and/or habitat variables comparing populations in parallel to measures of genetic differentiation aiming to decipher environmental differences between CUs); (vii) growth-forms sensu Raunkiaer (1934) (i.e. phanerophyte, nanophanerophyte, chamephyte, hemicryptophyte, geophyte, therophyte), which constitute a good proxi for a classification into broad functional groups; (viii) endemism type: we have taken into account, as much as possible, phylogenetic studies to get an accurate estimate of the tempo of divergence, and to distinguish palaeoendemics vs. neoendemics, i.e. respectively a differentiation before or after the Pliocene-Pleistocene transition (ca. $3 \mathrm{My}$ ); (ix) caryology, with indications of the chromosome number and the ploidy level according to the Chromosome Counts Database (CCDB, version 1.45: http://ccdb.tau.ac.il/home/), the Chrobase.it (Chromosome numbers for the Italian flora: http://bot.biologia.unipi.it/chrobase/index.php), and other sources notably Flora Iberica 
(Castroviejo, 1986-2015); (x) genetic data: genetic markers used, mean population genetic diversity $(\mathrm{He})$ and its standard deviation, plastid haplotype number, genetic differentiation (Fst, PhiST or equivalent); (xi) number of known populations, and putative extinct populations according to indications of Red data books and of national or regional floras; (xii) whole distribution area of the taxon considered as its extent of occurence sensu IUCN; (xiii) IUCN categories according to the IUCN Red list of threatened taxa (http://www.iucnredlist.org/), completed by indications in several national or regional Red data books (notably for Spain: Bañares et al. 2003-2010; France: UICN France et al. 2012, and Italy: Conti et al. 1997), or in particular papers related to the concerned taxa (see References A1).

\subsection{Data analysis}

The studies included into the data table (Table A1) were analyzed to summarize (i) the temporal trend of publications, (ii) molecular methods used to access genetic diversity, (iii) extent of mean population genetic diversity and genetic differentiation, (iv) reports by the authors of any geographical genetic structure that could lead to inference of phylogeographical structures, (v) explicit use of concepts based on phylogeography to set conservation priorities such as ESUs (Evolutionary Significant Units), CUs (Conservation Units), and MUs (Management Units) or equivalent. Comparison of diversity or differentiation measures across different studies based on different molecular markers, sampling efforts and methods is particularly risky and previously only the magnitude of values was compared (Fernández-Mazuecos et al. 2014; JiménezMejías et al. 2015). Here, the extent of genetic diversity or differentiation were summarized according to quartile limits (<Q1, Q1-median, median-Q3, $>$ Q3) to help analysis. We have looked only to the main trends: how frequent are studies reporting lack of or very low genetic diversity or genetic differentiation? How frequent are studies reporting high genetic diversity or differentiation? When data were provided by several methods of molecular markers, we used the values from nuclear markers. Results reported by authors about geographical structure of genetic diversity were summarized in Table A1, and then summarized according two categories: existence or not of any geographical genetic diversity structure. The same approach was used to assess conservation implications of the results provided by authors, i.e. if they use or not any concept associated to ESU, CU, MU or equivalent. Summary statistics of genetic diversity data from Table A1 are indicated in Table 1.

\section{Results}

\subsection{Insights about the studied narrow endemics}

Our critical review allowed us to retain 84 published studies between 1996 and 2017 (Figure 2; References A1), which correspond to 83 Mediterraneanean narrow endemic (MNE) plants (Table A1) since some taxa were analyzed several times, and on the other hand, some studies have included the analysis of different taxa. There was a strong geographical discrepancy because a large part $(54 \%, n=45)$ of the studied endemics occur in the Iberian Peninsula. 25 MNEs (i.e. 30\%) located in France and/or Italy (including the islands of Corsica, Sardinia and Sicily) were studied. The other Mediterranean territories are clearly under-sampled since only five taxa have been 
studied in North Africa (only in Morocco), and seven taxa in the eastern Mediterranean which includes countries (Turkey and Greece) characterized by very high level of endemic richness. These 83 MNEs are located at $60 \%$ on the continent and $40 \%$ on some large Mediterranean islands (in particular Balearic Islands: $n=15$; Sardinia: $n=7$; Sicily: $n=6$ ). We found that $75 \%$ of the MNEs are included in one (or more) of the 52 glacial refuge areas identified by phylogeographical studies, and that $65 \%$ of the MNEs occur in one of the 10 regional biodiversity hotspots of plants within the Mediterranean region.

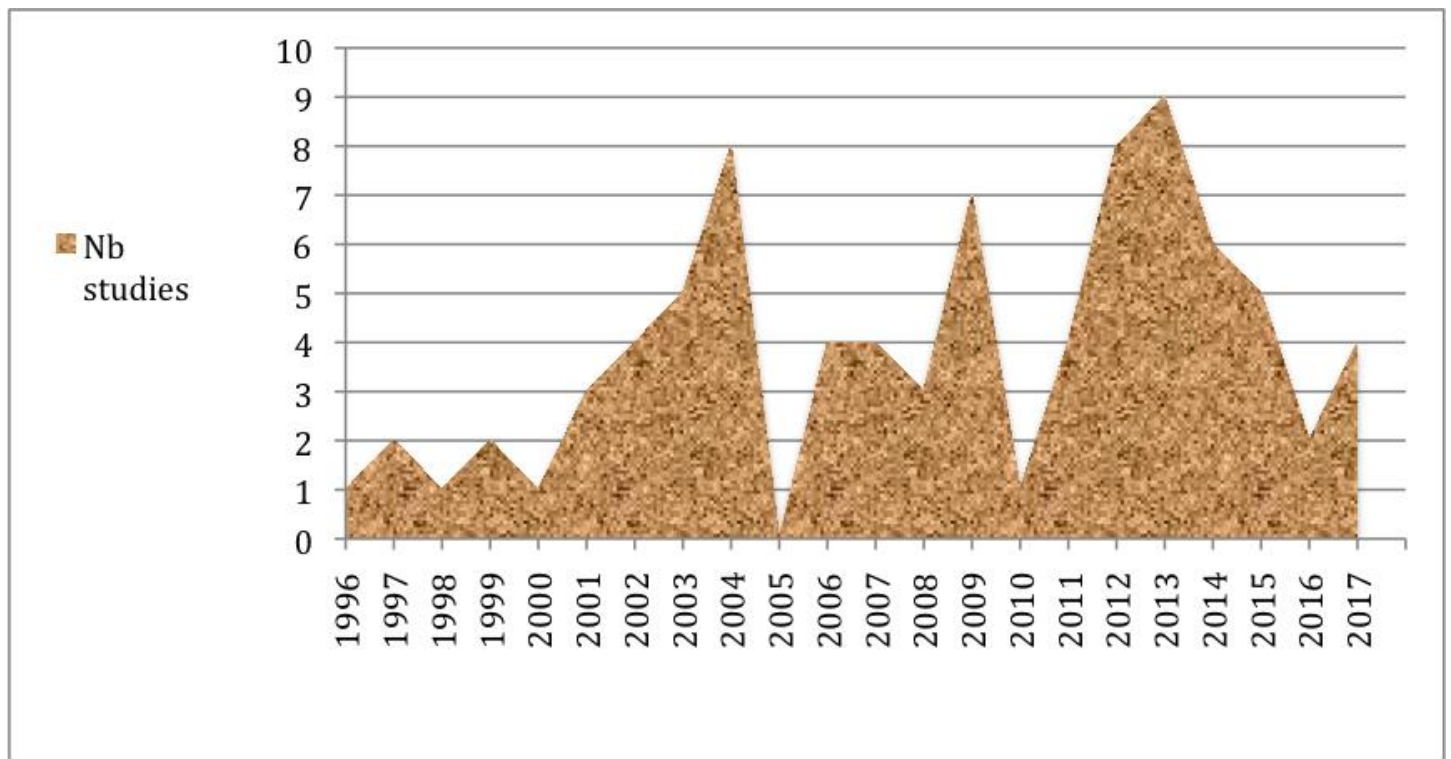

Fig. 2. Annual records of publications reporting the use of genetic data for Mediterranean narrow endemic plants (total nuber of studies $=84$, corresponding to 83 studied taxa).

If we consider the ecological and functional attributes, we note the preponderance of narrow endemics on limestone substrates $(41 \%, n=34)$, to the detriment of those present on siliceous outcrops (11\%). Ten taxa linked to highly specific substrates (gypsum, ultramafic or volcanic rocks) are included, and only eight that are indifferent to the nature of the substrate. Most of these endemics (ca. 80\%) are specialized taxa occuring in one $(n=25)$ or two $(n=41)$ major ecological habitat, whereas only five endemics possess a large ecological niche (number of habitats occupied $>4$ ). Almost all the endemics studied are perennial taxa $(\mathrm{n}=79$, i.e. $94 \%)$, since the main growth-forms sensu Raunkiaer (1934) are represented by low shrubs (chamephytes: $n=32$ ) and perennial herbs (hemicryptophytes: $\mathrm{n}=26$ ).

The evolutionary legacy of these narrow endemics includes, according to phylogenetic studies, $55 \%$ of neoendemics and $40 \%$ of palaeoendemics (only 4 taxa cannot be properly assigned to one of this category). Most of them $(70 \%$, i.e. $\mathrm{n}=58)$ are diploid taxa, whereas polyploids are infrequent $(n=18)$.

Finally, in relation to the IUCN Red List categories, two thirds of the endemics represent threatened taxa $(C R: n=16 ; E N: n=20 ; V U=19)$. Few taxa are therefore included into the categories of least threat (NT: $n=3 ; L C: n=14)$, the others being not evaluated $(\mathrm{n}=11)$ or data deficient $(\mathrm{n}=1)$. 
Table 1

Summary statistics of genetic diversity and differentiation for the 83 case-studies of Mediterranean narrow endemic plants (MNEs).

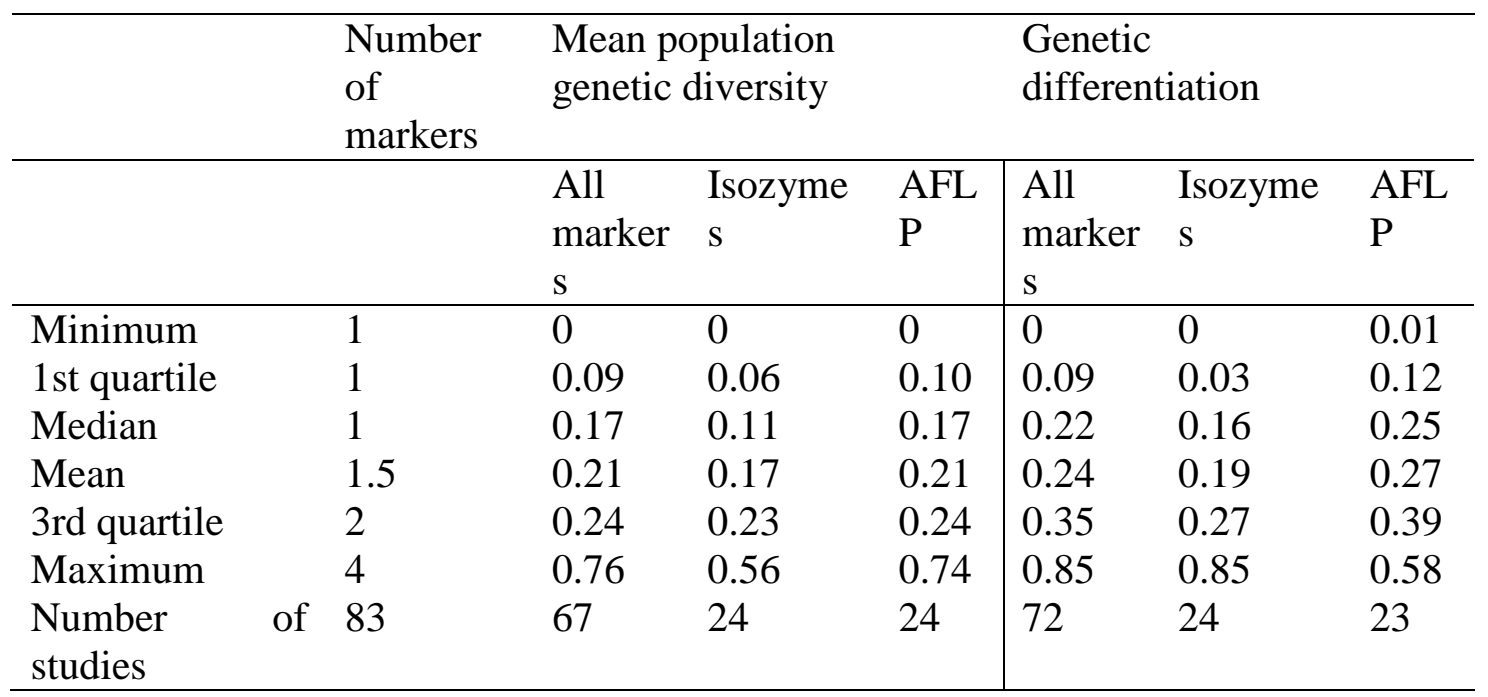

\subsection{Molecular markers and methods}

The makers used to assess genetic diversity of MNEs were, in decreasing frequency, AFLP (36\%), ptDNA sequences or RFLP (31\%), isozymes (30\%), ISSR (21\%), RAPD (14\%), rDNA ITS (10\%), SSR (7\%) and nuclear gene sequence (1\%). Sixty-two per cent of the studies were based on only one marker, $26.5 \%$ on two markers, $8 \%$ on three markers and $2 \%$ on four markers. When more than one molecular method was applied, the most common association was AFLP and plastid DNA markers. Interestingly, SSR markers, which were the most common markers for population genetics in the 1990s and the 2000s, were rarely used (7\%) and they are based on a low number of markers (median of 5); this pattern was mainly due to transfer of previously designed SSR loci from a related species and not specific development of SSR markers. About analytical methods, almost all studies were based on statistics describing genetic variance (Fst, AMOVA), often complemented by multivariate analyses (PCO, clustering) and Bayesian clustering (STRUCTURE or BAPS). Recent analytical methods designed were rarely used: coalescent methods were used three times (Blanco-Pastor et al. 2013, Christe et al. 2014, Jiménez-Mejías et al. 2015), ancestral areas modelling was performed only one time (Pouget et al. 2013), and Aproximate Bayesian Computing $(\mathrm{ABC})$ methods was never used.

\subsection{Genetic diversity summary}

Our review of data indicates that in general MNEs are not depleted in genetic diversity, since only $25 \%$ possess a low genetic diversity (inferior to $9.5 \%$ ) and $50 \%$ of the studies reported a mean population genetic diversity superior to $17 \%$ (all markers and AFLP median Table 1); this value is in agreement with a previous review of some 17 narrow endemic case studies reporting a majority of "moderate to high genetic diversity" (Jiménez-Mejías et al. 2015). The range of genetic differentiation was rather large with 
a first quartile at $9 \%$ and a third quartile at 35\% (Table1). Gene flow is most often limited in MNEs, with half of the studies reporting a moderate or high differentiation (i.e. Fst or Gst median $=0.16$ for isozyme and 0.25 for AFLP; Table 1). However, genetic differentiation is not always geographically structured with only $56 \%$ of the studies reporting a geographical pattern, even weak. Bivariate or multivariate analyses (non shown) failed to reveal any significant statistical correlations between genetic indices (diversity and differentiation, computed for all markers or by separating isozyme markers from AFLP markers, with any of the variables used to describe the studies).

\subsection{Design of conservation units}

Only $27 \%$ of the case studies showing a geographical structure of populations used explicitly this information to set conservation priorities, and finally only 15 studies (18\%) (for a total of 16 MNEs) inferred CUs, MUs, ESUs or Relevant genetic units for conservation (RGUCs) (Pérez-Collazos et al. 2008). Interestingly, 12 of these 15 studies were based on AFLP. Consequently, we observed a strong association between AFLP, geographical structure and the design of CUs.

\section{Discussion}

\subsection{Phylogeographical and genetic structures of Mediterranean narrow endemics (MNEs)}

\subsubsection{Insights of the data review}

An exhaustive literature survey of within-species phylogeographical works in the Mediterranean Basin hotspot allows us to retain 83 MNEs, which are part of 84 published papers between 1996 and 2017 (References A1). We fail to detect a significant increase in the number of publications over the years, because of an idiosyncratic rhythm of publications (Figure 2). These 83 MNEs here represent only $0.75 \%$ of the ca. 11,000 MNEs (see Introduction), i.e. a tiny part of the Mediterranean plant endemism. This lack of intraspecific phylogeographical studies on plants is not peculiar to the Mediterranean Basin, and other global biodiversity hotspots such as the Cape Floristic Region - although of much smaller size $\left(<90,000 \mathrm{~km}^{2}\right)$ - include even fewer studies, only 5 carried out until 2013 (see Lexer et al. 2013). Geographical coverage is also heavily biased since $91.5 \%$ of the analyzed MNEs are located in the north-western part of the Mediterranean Basin, in particular into the Iberian Peninsula, whereas $60 \%$ occur on the continent and $40 \%$ on Mediterranean islands. Concerning the ecological and functional traits of MNEs (Lavergne et al. 2003), the studied taxa exhibit a high habitat specialization ( $80 \%$ of the taxa), mainly on calcareous rocky outcrops or cliffs. Calcicolous taxa represent the major contingent $(41 \%)$, but it remains less important than the similar one $(60 \%)$ occuring within the endemic flora of a region like the south-east of France which is covered for about half limestone rocks (Médail \& Verlaque 1998). The studied MNEs are almost totally characterized by perenial growth forms (94\% of the taxa), and this is similar to the percentages obtained in various endemic flora of the MBR, where annual taxa are scarce and comprised between 6 and 15\% (Médail \& Verlaque 1998; Melendo et al. 2003). There is a balance between recent (55\% of neoendemics) and ancient lineages (40\% of palaeoendemics), but diploid MNEs predominate $(70 \%)$. The evolutionary legacy of these narrow endemics is 
correctly taken into account even if this panel is slightly unbalanced: palaeoendemics are indeed less frequent in various Mediterranean floras (15-17\% of the endemic floras in the East, 28-32\% in the West: see Verlaque et al. 1997).

Despite this strong eco-geographical discrepancy, the conservation biogeography framework (Ladle \& Whittaker 2011) is rather relevant since $65 \%$ of these MNEs occur in one of the 10 regional biodiversity hotspots of plants (Médail \& Quézel 1997), and $75 \%$ of the MNEs are included in one (or more) of the 52 identified glacial refuge areas (Médail \& Diadema 2009). Nevertheless, 24 of these refugias (i.e. $46 \%$ ) do not include any of the the studied MNEs, these "orphan refugias" are, again, mainly localized in the southern and eastern Mediterranean Basin.

\subsubsection{Main results from molecular ecology data}

By examining molecular methods, we observed that studies dealing with MNEs were based almost on "low cost" markers such as isozymes, or dominant markers $(72 \%$ RAPD, ISSR, AFLP). Only $31 \%$ of the case studies investigated plastid molecular variation and very few found enough plastid sequence variation to build a sensu stricto phylogeography approach based on maternal lineages and migration routes inference (e.g. Pouget et al. 2013). This limit could be due to the low mutation rate of plastid genomes and should be surpassed by whole plastid genome sequencing. However MNEs still do not benefit from Next generation sequencing (NGS) technology. We found only one study based on NGS (Filatov et al. 2016), but it was not incorporated in our review because of a focus on hybridization. Despite the importance of issues tackled by genomics, such as local adaptation and speciation, the least that can be said is that the cost of conservation genomics is seriously challenging for MNEs.

We note also that phylogeography as intitially defined (Avise et al. 1987, Diniz-Filho et al. 2008, Avise 2009) has been very rarely the aim of the studies dealing with genetic diversity of MNEs. Moreover, "up to date" analytical methods based on multi-locus approaches and taking into account the stochasticity of genetic processes (statistical phylogeography: Knowles \& Madisson 2002) were not used either, despite the fact that $77 \%$ of the studies were published after 2003. Statistical phylogeography allows to decipher the impact of past environmental changes on key demographic and biogeographical processes (local persistence, range shift, or adaptation) which are crucial for our understanding of MNEs' responses to future environmental changes.

Of course, not all MNEs have their genetic diversity geographically structured and some are characterized by a lack of genetic differentiation (first quartile below 9\%, Table 1) and one can doubt about the relevance of phylogeography for MNEs. However, half of the studied species have moderate to high genetic diversity (median 17.5\%, Table 1) within their populations, and gene flow appeared to be limited in majority of the case studies with $56 \%$ of the studies reporting a geographical structure. Such trends indicate that MNEs are not "evolutionary dead-ends" but are sheltering a strong evolutionary legacy that could fuel a high potential for diversification and further evolution. Moreover genetic differentiation among populations can also result from strong genetic drift due to limited gene flow and local population size decrease. In this case, genetic differentiation reflects the vulnerability of local populations to population size reduction which is a relevant issue for conservation.

\subsubsection{Conservation units of MNEs: a debriefing and perspectives}


All these results indicate that phylogeography and the design of conservation units could be a relevant issue for the long-term conservation of MNEs. But our review reported that only $27 \%$ of the studies (i.e. $n=15$ ) mentioning a geographical structure used explicitly this information to set conservation priorities of some populations. It is worrying since two thirds of these endemics represent threatened taxa sensu IUCN (CR $+\mathrm{EN}+\mathrm{VU}$ categories).

Analysis of these 15 cases studies revealed that the ESU concept was the most frequently used: seven papers have used it explicitly, and three used a terminology very close to that of ESU such as Significant evolutionary heritage (Christe et al 2014); these ten studies have inferred ESUs from genetic clusters. Conservation unit (CU) was used four times and Management unit (MU) only two times. Only two papers developed their own approach, the first one with the definition of Relevant genetic units for conservation (RGUC) (Pérez-Collazos et al. 2008), and the second one including a precise methodology to design how many and which populations to conserve for preserving 99\% of genetic diversity (Caujapé-Castells \& Pedrola-Montfort 2004). Only two papers introduced their issue with a short review of these concepts of conservation genetics (Pérez-Collazos et al. 2008, Pouget et al. 2017).

\subsection{Phylogeography, a neglected tool for conservation planning of endemic plants}

The general picture from this review is that the design of conservation units was generally overlooked and was not a priority issue, rather a way to enhance the scope of genetic diversity analyses. This is surprising since most of these studies were performed after the publication of the main review papers dealing with the relevance of conservation units (Ryder 1986, Moritz 1994, Crandall et al. 2000, Frazer \& Bernatchez 2001). This finding is not specific to MNEs because a more general search of literature applied to plants shows that few studies in the world are based on the use of the conservation unit concept.

In the context of weak financial support for biodiversity conservation in the MBR (see the strong geographical bias shown here), the efficiency of conservation science must be optimized. As emphasized by Avise (2009) phylogeography fills the gap between diversification that occurred long time ago, e.g. before the Pleistocene, and population divergence that occurred more recently, e.g. in the late Pleistocene or the Holocene: this is a "grey zone" where speciation is not fully accomplished. One role of phylogeography is to furnish a precise message to conservationists to help them to incorporate "microevolutionary processes" at a moderate financial cost (Diniz-Filho et al. 2008). Overlooking existence of phylogeography structure within species, for example by considering all populations as equal and exchangeable, will lead to an overlook and a risk of lost of irreplaceable evolutionary legacy and the "fuel" for responses to future environmental changes. Indeed, the concept of ESU was created to overcome this latter issue (Ryder 1986). On the other hand, the lack of comprehensive researches in systematics and uncertainties on evolutionary units can lead to an excessive splitting during the delineation of taxa that weaken research and conservation. Such problem is recurrent in some genera of the MBR, such as Anchusa, Centaurea, or Limonium and this eventually leads us to not include some case studies in this review because of incongruence between taxa swarm and genetic clusters, e.g. the endemic taxa of Aquilegia in Sardinia (Garrido et al. 2012) or the Genista ephedroides complex (De Castro et al. 2015). At this level, delineation of conservation units meets the issue of delineation of taxa, notably at the species rank (Frankham et al. 2012). 
Beyond case-by-case studies, geographical trends revealed by "comparative phylogeography" are the clues needed to define areas having a pivotal role for persistence (refugia), diversification (evolutionary cradle) or dispersal (large scale barriers or corridors), i.e. a crucial information for conservation planning at a regional or continental level (Carnaval et al. 2009; Lexer et al. 2013; Avise et al. 2016). But such approach was never applied to Mediterranean plants. It could be used (i) to link refugia biogeography (Médail \& Diadema 2009) with persistence and migration processes induced by past or current climatic changes, or (ii) to search for spatial congruence between phylogeographical approaches and those examining relative phylogenetic endemism (RPE: see Mishler et al. 2014), a metric allowing the distinction between centres of palaeo- and neo-endemism. But if a macroecological approach merging various metrics of evolutionary diversity (phylogenetic diversity, phylogenetic divergence and contrast between palaeo- and neo-endemism) was very rarely applied in the Mediterranean region (but see Molina-Venegas et al. 2017), it could be seriously weakened and biased according to taxonomy. Thus, again, a strong integrative systematics remains a crucial aspect for a robust conservation of Mediterranean plants (Simón Porcar et al. 2018).

Because of the very low number of MNEs studied, compared to their huge total diversity in the MBR, the design of conservation units according to an ideal scientific background evaluating genetic and ecological exchangeabilities as well as criteria associated to population fitness will be necessary impossible at the level of the Mediterranean region. Then, other approaches like the focus on species' adaptive variation contained in peripheral isolates (e.g. MacDonald et al. 2017) should be used to set conservation priorities in term of vulnerability and biogeography without requiring conservation genetics for each narrow endemic. For such issues, results from phylogeographies can be used to evaluate the efficiency of new methods to target key zones (ancestral areas, refugia, peripheral isolates and more generally source and sink of diversification) for the conservation of evolutionary diversity (Pouget et al. 2016).

\subsection{What are the urgencies for the conservation genetics of narrow endemic plants in the Mediterranean hotspot?}

Narrow endemic plants of the Mediterranean hotspot are mainly composed of a contingent of stress-tolerant taxa sensu Grime (Médail \& Verlaque 1997), able to overcome several environmental changes. This is illustrated sometimes by their local persistence in highly constrained ecological situations, for example along elevational gradient (e.g. Pouget et al. 2013). However, the concept of genetic and ecological exchangeability (Crandall et al. 2000) was very rarely used to design conservation priorities (Pouget et al. 2013, 2017) despite the importance of environmental heterogeneity and local adaptation for conservation issues within the MBR (Médail \& Quézel 1997).

The importance of the persistence process for the maintenance of local biodiversity is generally underestimated, or even not taken into account, in studies that model the biogeographical destiny of species in the face of global changes (but see Randin et al. 2009). The persistence by longevity and/or vegetative reproduction for long-lived plants in stable habitats such cliffs or rocky outcrops is a major biological trait that explain the long-term viability of relict narrow endemics in the MBR (García \& Zamora 2003, García 2008). Some recent studies that focused on the response of single species (e.g., Fazan et al. 2017, about the narrow Cretan endemic tree Zelkova abelicea) or on entire 
plant communities (e.g., Henne et al. 2015) underline also that we may have underestimated the ecological amplitude and tolerance to climatic changes of many socalled 'temperate' species that thrive on Mediterranean mountains but could tolerate drier and warmer climates.

These patterns probably explain why most of the analyzed studies have focused on the long-lived MNEs occuring on stable ecosystems, notably cliff and other rocky habitats. We may note that there could be a bias related to the presence of MNEs in stable and "protected" habitats such as cliffs, possibly because recurent overgrazing by goats and sheeps has already dramatically reduced in more exposed habitats the populations of (other) MNEs devoid of efficient enough adaptation to resist to herbivory pressures. Feral or domesticated herbivores may be indeed a serious problem in some areas, especially on small Mediterranean islands (e.g., Bergmeier \& Dimopoulos 2003).

Therefore, there is a crucial need to focus on other plant functional groups, especially on short-lived endemics (annuals and biennials) localized in other habitats than the rupicolous ones. To fill these functional gaps would allow us to better understand the biological and ecological response of the other contingents of MNEs to the current environmental changes. Narrow endemics linked to highly vulnerable and threatened habitats, particularly those in coastal areas and low altitude wetlands, deserve a particular focus because these territories directly suffer the profound human impacts induced by the artificialisation and fragmentation of ecosystems (Blondel \& Médail 2009, Beltrame et al. 2012). Indeed, demands on biocapacity now exceed the Mediterranean region's supply by more than 150 percent (Galli et al. 2012), and this hotspot area has lost at least c. 50\% of the wetlands that existed in 1900 (Beltrame et al. 2012).

This review demonstrates also the deep geographical unbalance between the western and eastern basins, since a large majority of studies $(90.5 \%)$ concern the western part whereas only seven narrow endemics of the eastern Mediterranean could be included in this analysis. This distortion does not reflect at all the distribution of the major hotspots of Mediterranean endemism. There is in fact a bipolar concentration of plant endemism on both sides of the Mediterranean Basin (Médail \& Quézel 1997): (i) in the eastern basin, in Turkey (including Irano-Turanian and Euro-Siberian regions) with ca. 3100 endemic species (endemism rate of 31\%: Şekercioğlu et al. 2011, modified) and in Greece with 1459 endemic taxa (endemism rate of $22 \%$ : Dimopoulos et al. 2016); (ii) in the western basin, in Spain (mainland + Balearics islands) with 1335 endemic taxa (endemism rate of 19.3\%: Aedo et al. 2013), and Morocco with 879 endemic taxa (endemism rate of 18.7\%: Rankou et al. 2013). We thus note the enormous gaps in the knowledge of the genetic structures of this still little studied group, and the consequences that this entails in the conservation prioritization.

It is therefore necessary to develop research on the least studied functional groups of narrow endemics (annuals and biennial herbs), on the less stable habitats which are the most threatened by landscape dynamics (grasslands, wetlands, forest edges), and on the least known regional hotspots of the MBR (Maghreb, Balkans, Levant, Turkey).

\section{Conclusions}

Our review, although based on almost all the studies related to the genetic structure of narrow endemic plants of the Mediterranean hotspot, clearly shown that a strong genetic differentiation is potentially present within these taxa and that phylogeography is a highly relevant approach to set conservation priorities. However systematics, 
phylogeography and conservation units must be linked by the need to clearly delineate evolutionary entities. Profound progresses on these three issues are needed for a better knowledge and a robust conservation biogeography of narrow endemics. Integrative approaches based on biological, ecological, genetic and even genomic data are also needed, in relation with a good characterization of the environmental heterogeneity of habitats on the local and micro scales (e.g. Mee \& Moore 2014). Added to the functional and geographic gaps shown here, the challenge is therefore outrageously high. Conservation biogeography researches dealing with ecological and biological uncertainties associated to our lack of knowledge on cryptic evolutionary legacy are therefore needed for one of the largest and hottest biodiversity hotspot of the world.

\section{Acknowledgments}

We thank Prof. François Munoz for his invitation to write this review for this special issue of Biological Conservation "Making sense of the multiple facets of rarity for conservation" and for his comments and improvements on the preliminary drafts of the manuscript, to Dr. Katia Diadema and Manuel Cartereau for some unpublished data concerning the Mediterranean narrow endemics analyzed in this review.

\section{References}

Aedo, C., Medina, L., Fernández-Albert, M., 2013. Species richness and endemicity in the Spanish vascular flora. Nordic J. Bot. 31, 478-488. http://dx.doi.org/10.1111/j.17561051.2012.00009.x

Bañares, Á., Blanca, G., Güemes, J., Moreno, J.C., Ortiz, S., (eds.), 2003-2010. Atlas y libro rojo de la flora vascular amenazada de España. Taxones prioritarios and adenda 2006, 2008, 2010. Dirección General de Medio Natural y Política Forestal (Ministerio de Medio Ambiente, y Medio Rural y Marino) \& Sociedad Española de Biología de la Conservación de Plantas, Madrid.

Avise, J.C., 2009. Phylogeography: retrospect and prospect. J. Biogeogr. 36, 3-15. http://dx.doi.org/10.1111/j.1365-2699.2008.02032.x

Avise, J.C., Arnold, J., Ball, R.M., Jr, Bermingham, E., Lamb,T., Neigel, J.E., Reeb, C.A., Saunders, N.C., 1987. Intraspecific phylogeography: the mitochondrial DNA bridge between population genetics and systematics. Annu. Rev. Ecol. Evol. Syst. 18, 489-522. https://doi.org/10.1146/annurev.es.18.110187.002421

Avise, J.C., Bowen, B.W., Ayala, F.J., 2016. In the light of evolution X: comparative phylogeography. PNAS 113, 7957-7961. https://doi.org/10.1073/pnas.1604338113

Beltrame, C., Chazée, L., Galewski, T., Perennou, C., 2012. Mediterranean wetlands: outlook. First Mediterranean wetlands observatory report. Technical report. Tour du Valat, Arles, France. (http://www.tourduvalat.org/sites/default/files/mwo_2012_report_en.pdf)

Bergmeier, E., Dimopoulos, P., 2003. The vegetation of islets in the Aegean and the relation between the occurrence of islet specialists, island size, and grazing. Phytocoenologia 33, 447-474. http://dx.doi.org/10.1127/0340-269X/2003/0033-0447

Blanco-Pastor, J.L., Fernández-Mazuecos, M., Vargas, P., 2013. Past and future 
demographic dynamics of alpine species: limited genetic consequences despite dramatic range contraction in a plant from the Spanish Sierra Nevada. Mol. Ecol. 22, 4177-4195. http://dx.doi.org/10.1111/mec.12383

Blasi, C., Carranza, M.L., Filesi, L., Tilia, A., Acosta, A., 1999. Relation between climate and vegetation along a mediterranean-temperate boundary in central Italy. Global Ecol. Biogeogr. 8, 17-27. https://doi.org/10.1046/j.1365-2699.1999.00121.x

Blondel, J., Médail, F., 2009. Biodiversity and conservation. In J.C. Woodward (ed.), The physical geography of the Mediterranean. Oxford University Press, Oxford, UK, pp. 615-650.

Cadotte, M.W., Davies, T. J., 2010. Rarest of the rare: advances in combining evolutionary distinctiveness and scarcity to inform conservation at biogeographical scales. Divers. Distrib. 16, 376-385. http://dx.doi.org/10.1111/j.14724642.2010.00650.x

Caesar, M., Grandcolas, P., Pellens, R., 2017. Outstanding micro-endemism in New Caledonia: more than one out of ten animal species have a very restricted distribution range. PLoS ONE 12(7), e0181437. https://doi.org/10.1371/journal.pone.0181437

Cañadas, E.M., Fenu, G., Peñas, J., Lorite, J., Mattana, E., Bacchetta, G., 2014. Hotspots within hotspots: endemic plant richness, environmental drivers, and implications for conservation. Biol. Conserv. 170, 282-291. http://dx.doi.org/10.1016/j.biocon.2013.12.007

Carnaval, A.C., Hickerson, M.J., Haddad, C.F., Rodrigues, M.T., \& Moritz, C., 2009. Stability predicts genetic diversity in the Brazilian Atlantic forest hotspot. Science 323, 785-789. http://dx.doi.org/ 10.1126/science.1166955

Carvalho, S.B., Velo-Antón, G., Tarroso, P., Portela, A.P., Barata, M., Carranza, S., Moritz, C., Possingham, H.P., 2017. Spatial conservation prioritization of biodiversity spanning the evolutionary continuum. Nature Ecol. Evol. 1, 0151. http://dx.doi.org/10.1038/s41559-017-0151

Casazza, G., Giordani, P., Benesperi, R., Foggi, B., Viciani, D., Filigheddu, R., Farris, E., Bagella, S., Pisanu, S., Mariotti, M.G., 2014. Climate change hastens the urgency of conservation for range-restricted plant species in the central-northern Mediterranean region. Biol. Conserv. 179, 129-138. http://dx.doi.org/10.1016/j.biocon.2014.09.015

Castroviejo, S. (coord. gen.), 1986-2015. Flora iberica. vol. 1-15, 17-18, 21. Real Jardín Botánico, CSIC, Madrid, Spain.

Caujapé-Castells, J., Pedrola-Monfort, J., 2004. Designing ex-situ conservation strategies through the assessment of neutral genetic markers: Application to the endangered Androcymbium gramineum. Conserv. Genet. 5, 131-134. https://doi.org/10.1023/B:COGE.0000029997.59502.88

Christe, C., Kozlowski, G., Frey, D., Bétrisey, S., Maharramova, E., Garfì, G., Stergios Pirintsos, S., Naciri, Y., 2014. Footprints of past intensive diversification and structuring in the genus Zelkova (Ulmaceae) in south-western Eurasia. J. Biogeogr. 41, 1081-1093. http://dx.doi.org/doi:10.1111/jbi.12276

Conti, F., Manzi, A., Pedrotti, F., (eds.), 1997. Liste rosse regionali delle Piante d'Italia. WWF-Società Botanica Italiana, Camerino, Italy.

Crandall, K.A., Bininda-Emonds, O.R.P., Mace, G.M., Wayne, R.K., 2000. Considering evolutionary processes in conservation biology. Trends Ecol. Evol. 15, 290-295. 
https://doi.org/10.1016/S0169-5347(00)01876-0

De Castro, O., Véla, E., Vendramin, G.G., Gargiulo, R., Caputo, P., 2015. Genetic structure in the Genista ephedroides complex (Fabaceae) and implications for its present distribution. Bot. J. Linn. Soc. 177, 607-618. https://doi.org/10.1111/boj.12263

Deil, U., Galan de Mera, A., 1996. Contribution à la connaissance de la phytosociologie et de la biogéographie des groupements rupicoles calcaires du Maroc. Bull. Inst. Sci., Rabat 20, 87-111.

Devictor, V., Mouillot, D., Meynard, C., Jiguet, F., Thuiller, W., Mouquet, N., 2010. Spatial mismatch and congruence between taxonomic, phylogenetic and functional diversity: the need for integrative conservation strategies in a changing world. Ecol. Lett. 13, 1030-1040. http://dx.doi.org/10.1111/j.1461-0248.2010.01493.x

Dimopoulos, P., Raus, Th., Bergmeier, E., Constantinidis, Th., Iatrou, G., Kokkini, S., Strid A., Tzanoudakis, D., 2016. Vascular plants of Greece: an annotated checklist. Supplement. Willdenowia 46, 301-347. http://dx.doi.org/10.3372/wi.46.46303

Diniz-Filho, J.A.F., Campos Telles, M., Bonatto, S., Eizirik, E., de Freitas, T., Marco, P., Santos, F., Sole-Cava, A., Soares, T., 2008. Mapping the evolutionary twilight zone: molecular markers, populations and geography. J. Biogeogr. 35, 753-763. http://dx.doi.org/10.1111/j.1365-2699.2008.01912.x

Fazan, L., Guillet, S., Corona, C., Kozlowski, G., Stoffel, M., 2017. Imprisoned in the Cretan mountains: how relict Zelkova abelicea (Ulmaceae) trees cope with Mediterranean climate. Sci. Total Environ. 599-600, 797-805. http://dx.doi.org/10.1016/j.scitotenv.2017.04.047

Fernández-Mazuecos, M., Jiménez-Mejías, P., Rotllan-Puig, X., Vargas, P., 2014. Narrow endemics to Mediterranean islands: moderate genetic diversity but narrow climatic niche of the ancient, critically endangered Naufraga (Apiaceae). Perspect. Plant Ecol. 16, 190-202. http://dx.doi.org/10.1016/j.ppees.2014.05.003

Forest, F., Grenyer, R., Rouget, M., Davies, T. J., Cowling, R. M., Faith, D. P., Balmford, A., Manning, J. C., Proches, S., van der Bank, M., Reeves, G., Hedderson, T. A. J. et Savolainen, V., 2007. Preserving the evolutionary potential of floras in biodiversity hotspots. Nature 445, 757-760. http://dx.doi.org/10.1038/nature05587

Fraser, D.J., Bernatchez, L., 2001. Adaptive evolutionary conservation: towards a unified concept for defining conservation units. Mol. Ecol. 10, 2741-2752. http://dx.doi.org/10.1046/j.0962-1083.2001.01411.x

Filatov, D.A., Osborne, O.G., Papadopulos, A.S., 2016. Demographic history of speciation in a Senecio altitudinal hybrid zone on Mt. Etna. Mol. Ecol. 25, 2467-2481. http://dx.doi.org/10.1111/mec.13618

Galli, A., Moore, M., Brooks, N., Iha, K., Cranston, G., 2012. Mediterranean ecological footprint trends. Report published by Global Footprint Network, in collaboration with WWF Mediterranean, UNESCO Venice and Plan Bleu. Global Footprint Network, Chatelaine (Geneva), Switzerland.

García, D., Zamora, R., 2003. Persistence, multiple demographic strategies and conservation in long-lived Mediterranean plants. J. Veg. Sci. 14, 921-926. http://doi.org/10.1111/j.1654-1103.2003.tb02227.x 
García, M.B., 2008. Life history and population size variability in a relict plant. Different routes towards long-term persistence. Divers. Distrib. 14, 106-113. http://doi.org/10.1111/j.1472-4642.2007.00429.x

Garrido, J.L., Fenu, G., Mattana, E., Bacchetta, G., 2012. Spatial genetic structure of Aquilegia taxa endemic to the island of Sardinia. Ann. Bot. 109, 953-964. http://doi.org/10.1093/aob/mcs011

Gaston, K.J., 1994. Rarity. Chapman \& Hall, London, UK .

Gaston, K.J., 2012. The importance of being rare. Nature 487, 46-47. http://doi.org/10.1038/487046a

Greuter, W., 1991. Botanical diversity, endemism, rarity, and extinction in the Mediterranean area: an analysis based on the published volumes of Med-Checklist. Bot. Chron. 10, 63-79.

Harrison, S., Noss, R., 2017. Endemism hotspots are linked to stable climatic refugia. Ann. Bot. 119, 207-214. http://doi.org/10.1093/aob/mcw248

Henne, P.D., Elkin, C., Franke, J., Colombaroli, D., Calò, C., La Mantia, T., Pasta, S., Conedera, M., Dermody, O., Tinner, W., 2015. Reviving extinct Mediterranean forests communities may improve ecosystem potential in a warmer future. Front. Ecol. Environ. 13, 356-362. http://dx.doi.org/10.1890/150027

Hoekstra, J.M., Boucher, T.M., Ricketts, T.H., Roberts, C., 2005. Confronting a biome crisis: global disparities of habitat loss and protection. Ecol. Lett. 8, 23-29. http://dx.doi.org/10.1111/j.1461-0248.2004.00686.x

Jarzyna, M., Jetz, W., 2016. Detecting the multiple facets of biodiversity. Trends Ecol. Evol. 31, 527-538. http://dx.doi.org/10.1016/j.tree.2016.04.002

Jetz, W., Rahbek, C., Colwell, R.K., 2004. The coincidence of rarity and richness and the potential signature of history in centres of endemism. Ecol. Lett. 7, 1180-1191. http://doi.org/10.1111/j.1461-0248.2004.00678.x

Jiménez-Mejías, P., Fernández-Mazuecos, M., Amat, M.E., Vargas, P., 2015. Narrow endemics in European mountains: high genetic diversity within the monospecific genus Pseudomisopates (Plantaginaceae) despite isolation since the late Pleistocene. J. Biogeogr. 42, 1455-1468. http://dx.doi.org/10.1111/jbi.12507

Klausmeyer, K.R., Shaw, M.R., 2009. Climate change, habitat loss, protected areas and the climate adaptation potential of species in Mediterranean ecosystems worldwide. PLoS ONE 4(7), e6392. http://doi.org/10.1371/journal.pone.0006392

Knowles, L.L., Maddison, W.P., 2002. Statistical phylogeography. Mol. Ecol. 11, 2623-2635. http://doi.org/10.1046/j.1365-294X.2002.01410.x

Kreft, H., Jetz, W., 2010. A framework for delineating biogeographical regions based on species distributions. J. Biogeogr. 37, 2029-2053. http://doi.org/10.1111/j.13652699.2010.02375.x

Kruckeberg, A.R., Rabinowitz, D., 1985. Biological aspects of endemism in higher plants. Annu. Rev. Ecol. Syst. 16, 447-479. https://doi.org/10.1146/annurev.es.16.110185.002311

Ladle, R.J., Whittaker, R.J. (eds), 2011. Conservation biogeography. Wiley-Blackwell, Chichester, UK. 
Lavergne, S., Garnier, E., Debussche, M., 2003. Do rock endemic and widespread plant species differ under the Leaf-Height-Seed plant ecology strategy scheme? Ecol. Lett. 6, 398-404. http://dx.doi.org/10.1046/j.1461-0248.2003.00456.x

Lexer, C., Mangili, S., Bossolini, E., Forest, F., Stölting, K.N., Pearman, P.B., Zimmermann, N.E., Salamin, N., 2013. Next generation' biogeography: towards understanding the drivers of species diversification and persistence. J. Biogeogr. 40, 1013-1022. http://dx.doi.org/10.1111/jbi.12076

López-Pujol, J., Martinell, M.C., Masso, S., Blanché, C., Sáez, L., 2013. The 'paradigm of extremes': extremely low genetic diversity in an extremely narrow endemic species, Coristospermum huteri (Umbelliferae). Plant Syst. Evol. 299, 439-446. http://dx.doi.org/doi/10.1007/s00606-012-0732-3

Macdonald, S.L., Llewelyn, J., Moritz, C., Phillips, B.L., 2017. Peripheral isolates as sources of adaptive diversity under climate change. Front. Ecol. Evol. 5, 88. https://doi.org/10.3389/fevo.2017.00088

Médail, F., Diadema, K., 2009. Glacial refugia influence plant diversity patterns in the Mediterranean Basin. J. Biogeogr. 36, 1333-1345. http://dx.doi.org/10.1111/j.13652699.2008.02051.x

Médail, F., Myers, N., 2004. Mediterranean Basin. In R.A. Mittermeier, Gill P. Robles, M. Hoffmann, J. Pilgrim, T. Brooks, C.G. Mittermeier, J. Lamoreux, G.A.B. da Fonseca, eds., Hotspots revisited: Earth's biologicaly richest and most endangered terrestrial ecoregions. CEMEX (Monterrey), Conservation International (Washington) and Agrupación Sierra Madre (Mexico), pp. 144-147.

Médail, F., Quézel, P., 1997. Hot-spots analysis for conservation of plant biodiversity in the Mediterranean Basin. Ann. Missouri Bot. Gard. 84, 112-127. http://dx.doi.org/10.2307/2399957

Médail, F., Verlaque, R., 1997. Ecological characteristics and rarity of endemic plants from southeast France and Corsica: implications for biodiversity conservation. Biol. Conserv. 80, 269-281. https://doi.org/10.1016/S0006-3207(96)00055-9

Meddour, R., 2010. Bioclimatologie, phytogéographie et phytosociologie en Algérie. $\mathrm{PhD}$ Thesis, University of Tizi Ouzou, Algeria.

Mee, J.A, Moore, J.-S., 2014 The ecological and evolutionary implications of microrefugia. J. Biogeogr. 41, 837-841. http://dx.doi.org/10.1111/jbi.12254

Melendo, M., Giménez, E., Cano, E., Gómez Mercado, F., Valle, F., 2003. The endemic flora in the south of the Iberian Peninsula: taxonomic composition, biological spectrum, pollination, reproductive mode and dispersal. Flora 198, 260-276. https://doi.org/10.1078/0367-2530-00099

Mishler, B.D., Knerr, N., González-Orozco, C.E., Thornhill, A.H., Laffan, S.W., Miller, J.T., 2014. Phylogenetic measures of biodiversity and neo- and paleo-endemism in Australian Acacia. Nature Comm. 5, 4473. https://doi.org/10.1038/ncomms5473

Molina-Venegas, R., Aparicio, A., Lavergne, S., Arroyo, J., 2017. Climatic and topographical correlates of plant palaeo- and neoendemism in a Mediterranean biodiversity hotspot. Ann. Bot. 119, 229-238. http://dx.doi.org/10.1093/aob/mcw093

Moritz, C.C., 1994. Defining "Evolutionarily Significant Units" for conservation. Trends Ecol. Evol. 9, 373-375. http://dx.doi.org/10.1016/0169-5347(94)90057-4 
Moritz, C.C., Potter S., 2013. The importance of an evolutionary perspective in conservation policy planning. Mol Ecol 22, 5969-5971. http://dx.doi.org/10.1111/mec.12565

Mouillot, D., Bellwood, D.R., Baraloto, C., Chave, J., Galzin, R., Kulbicki, M., et al., 2013. Rare species support vulnerable functions in high diversity ecosystems. Plos Biol. 11(5), e1001569. https://doi.org/10.1371/journal.pbio.1001569

Mouquet, N., Devictor, V., Meynard, C.N., Munoz, F., Bersier, L.-F., Chave, J., Couteron, P., Dalecky, A., Fontaine, C., Gravel, D., Hardy, O.J., Jabot, F., Lavergne, S., Leibold, M., Mouillot, D., Münkemüller, T., Pavoine, S., Prinzing, A., Rodrigues, A.S.L., Rohr, R.P., Thébault, E., Thuiller, W., 2012. Ecophylogenetics: advances and perspectives. Biol. Rev. 87, 769-785. http://dx.doi.org/10.1111/j.1469185X.2012.00224.X

Nielsen, E.S., Beger, M., Henriques, R., Selkoe, K.A., von der Heyden, S., 2016. Multispecies genetic objectives in spatial conservation planning. Conserv. Biol. 31, 872-882. http://dx.doi.org/10.1111/cobi.12875

Ohlemüller, R., Anderson, B.J., Araújo, M.B., Butchart, S.H.M., Kudrna, O., Ridgely, R.S., Thomas, C.D., 2008. The coincidence of climatic and species rarity: high risk to small-range species from climate change. Biol. Lett. 4, 568-572. http://dx.doi.org/10.1098/rsbl.2008.0097

Parolly, G., 2004. The high mountain vegetation of Turkey - a state of the art report, including a first annotated conspectus of the major syntaxa. Turk. J. Bot. 28, 39-63.

Pérez-Collazos, E., Segarra-Moragues, J.G., Catalán, P., 2008. Two approaches for the selection of relevant genetic units for conservation in the narrow European endemic steppe plant Boleum asperum (Brassicaceae). Biol. J. Linn. Soc. 94, 341-354. http://dx.doi.org/10.1111/j.1095-8312.2008.00961.x

Peterson, A.T., Watson D.M., 1998. Problems with areal definitions of endemism: the effects of spatial scaling. Divers. Distrib. 4, 189-194. http://dx.doi.org/10.1046/j.14724642.1998.00021.x

Pollock, L.J., Rosauer, D.F., Thornhill, A.H., Kujala, H., Crisp, M.D., Miller, J.T., McCarthy, M.A., 2015. Phylogenetic diversity meets conservation policy: small areas are key to preserving eucalypt lineages. Phil. Trans. R. Soc. B 370, 20140007. http://dx.doi.org/10.1098/rstb.2014.0007

Pollock, L.J., Thuiller, W., Jetz, W., 2017. Large conservation gains possible for global biodiversity facets. Nature 546 (7656), 141-144. http://dx.doi.org/10.1038/nature22368

Pouget M., Youssef S., Migliore J., Juin M., Médail F., Baumel A., 2013. Phylogeography sheds light on the central-marginal hypothesis in a Mediterranean narrow endemic plant. Ann. Bot. 112, 1409-1420. http://dx.doi.org/10.1093/aob/mct183

Pouget, M., Youssef, S., Dumas, P. J., Baumberger, T., San Roman, A., Torre, F., Affre L., Médail F. \& Baumel, A. 2016. Spatial mismatches between plant biodiversity facets and evolutionary legacy in the vicinity of a major Mediterranean city. Eco. Ind. 60: 736745.

Pouget, M., Baumel, A., Diadema, K., Médail, F., 2017. Conservation unit allows assessing vulnerability and setting conservation priorities for a Mediterranean endemic plant within the context of extreme urbanization. Biodiv. Conserv. 26, 293-307. http://dx.doi.org/10.1007/s10531-016-1242-3 
Quézel, P., Barbero, M., 1985. Carte de la végétation potentielle de la région méditerranéenne. Feuille ${ }^{\circ} 1$ : Méditerranée orientale. CNRS, Paris.

Randin, C.F., Engler, R., Normand, S., Zappa, M., Zimmermann, N.E., Pearman, P.B., Vittoz, P., Thuiller, W., Guisan, A., 2009. Climate change and plant distribution: local models predict high-elevation persistence. Global Change Biol. 15, 1557-1569. https://doi.org/10.1111/j.1365-2486.2008.01766.x

Rankou, H., Culham, A., Jury, S.L., Christenhusz, M.J.M., 2013. The endemic flora of Morocco. Phytotaxa 78, 1-69. http://dx.doi.org/10.11646/phytotaxa.78.1.1

Raunkiaer, C., 1934. The life form of plants and statistical plant geography. Oxford University Press, Oxford, UK.

Rivas-Martínez, S., Penas, A., Díaz, T.E., 2004. Biogeographic map of Europe. In Worldwide bioclimatic classification system. University of León, Spain. (http://www.globalbioclimatics.org/form/maps.htm)

Ryder, O.A., 1986. Species conservation and systematics: the dilemma of subspecies. Trends Ecol. Evol. 1, 9-10. http://dx.doi.org/10.1016/0169-5347(86)90059-5

Sandel, B., Arge, L., Dalsgaard, B., Davies, R.G., Gaston, K.J., Sutherland, W.J., Svenning, J.-C., 2011. The influence of Late Quaternary climate-change velocity on species endemism. Science 334, 660-664. http://dx.doi.org/10.1126/science.1210173

Şekercioğlu, C.H., Anderson, S., Akcay, E., Bilgin, R., Can, Ö.E., Semiz, G., Tavsanoğu, C., Yokes M.B., Soyumert, A., Ipekdal, K., Sağlam, I.K., Yücel, M., Dalfes, H.N., 2011. Turkey's globally important biodiversity in crisis. Biol. Conserv. 144, 2752-2769. http://dx.doi.org/10.1016/j.biocon.2011.06.025

Simón Porcar, V.I., Escudero, M., Sampedro, L., De Castro, A., Lorite, J., MolinaVenegas, R., Arroyo, J., 2018. Using floristics, modern systematics and phylogenetics for disentangling biodiversity hotspots across scales: a Mediterranean case study. Pl. Biosyst., in press. https://doi.org/10.1080/11263504.2018.1445131

Swarts, N.D., Clements, M.A., Bower, C.C., Miller, J.T., 2014. Defining conservation units in a complex of morphologically similar, sexually deceptive, highly endangered orchids. Biol. Conserv. 174, 55-64. https://doi.org/10.1016/j.biocon.2014.03.017

Thompson, J.D., 2005. Plant evolution in the Mediterranean. Oxford University Press, Oxford.

Thuiller, W., Guéguen, M., Georges, D., Bonet, R., Chalmandrier, L., Garraud, L., Renaud, J., Roquet, C., Van Es, J., Zimmermann, N.E., Lavergne, S., 2014. Are different facets of plant diversity well protected against climate and land cover changes? A test study in the French Alps. Ecography 37, 1254-1266. http://dx.doi.org/doi: 10.1111/ecog.00670

Tucker, C.M., Cadotte, M.W., Davies, T.J., Rebelo, T.G., 2012. Incorporating geographical and evolutionary rarity into conservation prioritization. Conserv Biol. 26, 593-601. http://dx.doi.org/10.1111/j.1523-1739.2012.01845.x

Verlaque, R., Médail, F., Quézel, P., Babinot, J.-F., 1997. Endémisme végétal et paléogéographie dans le bassin méditerranéen. Geobios, mém. sp. 21, 159-166. https://doi.org/10.1016/S0016-6995(97)80083-6

UICN France, FCBN, MNHN, 2012. La Liste rouge des espèces menacées en France Chapitre Flore vasculaire de France métropolitaine : premiers résultats pour 1000 espèces, sous-espèces et variétés. UICN France, Paris, France. 
